(2)

OPEN ACCESS

\title{
TACO and TRALI: visualising transfusion lung injury on plain film
}

\author{
Caroline E Murphy, Colin M Kenny, Kevin F Brown
}

Tripler Army Medical Center, Tripler, Hawaii, USA

\section{Correspondence to} Dr Caroline E Murphy, caroline.e.murphy.mil@mail.mil

Accepted 7 August 2019

\section{DESCRIPTION}

A 63-year-old woman with poorly controlled type 2 diabetes mellitus was admitted to the intensive care unit for increased respiratory support following large-volume fluid administration to treat diabetic ketoacidosis. The patient was intubated and diagnosed with mild acute respiratory distress syndrome; the clinical status was improving when a unit of blood was administered for chronic anaemia. Ten minutes into blood administration, the patient became acutely hypoxic (SpO2 70\%) and hypertensive $(200 / 100 \mathrm{~mm} \mathrm{Hg})$. Administration was halted, and a stat chest X-ray (CXR) obtained. Clinical examination was notable for prominent jugular venous distension, unremarkable on earlier examination. A morning CXR obtained 90 min prior (figure 1) was compared with the one obtained post-reaction (figure 2), demonstrating sudden, dramatic worsening of bilateral lung opacities. Supportive care was initiated with oxygen and diuresis, and the symptoms resolved $30 \mathrm{~min}$ following cessation of blood product administration. Investigation of blood products for human leukocyte antigen (HLA) antibodies and human neutrophil antigen (HNA) antibodies was initiated and ultimately was negative. It was determined that the clinical presentation and symptoms were most consistent with transfusion-associated circulatory overload (TACO).

TACO and transfusion-related acute lung injury (TRALI) are acute respiratory distress syndromes that are often difficult to distinguish. ${ }^{1}$ Several different clinical definitions of TACO and TRALI have been proposed by various societies. ${ }^{1}$ However,

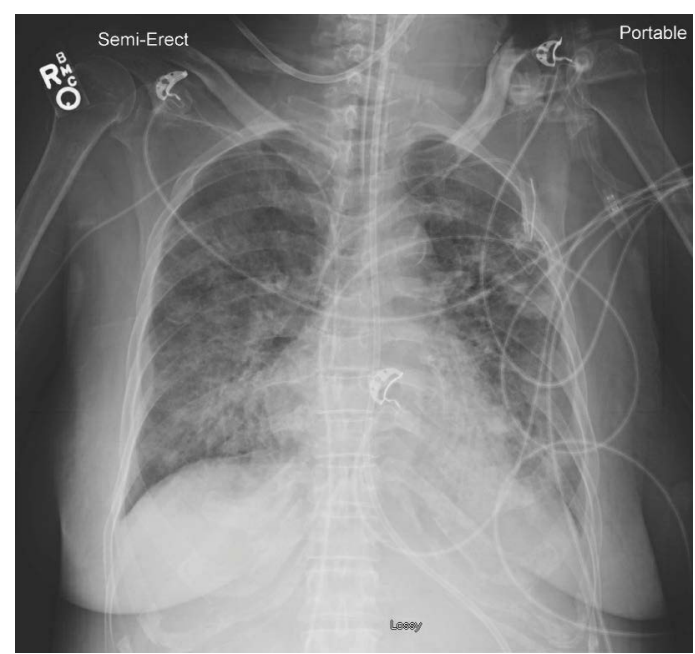

Figure 1 Portable anteroposterior (AP) chest X-ray prior to transfusion. Diffuse bilateral airspace opacities.

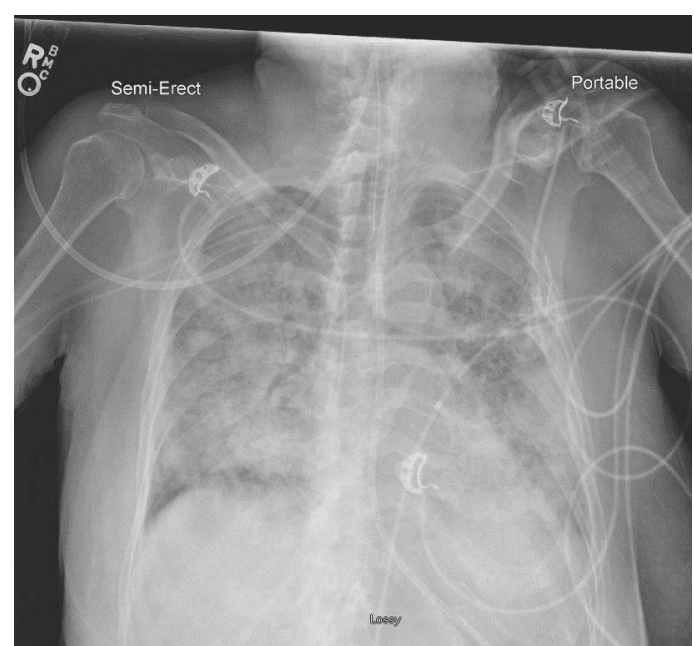

Figure 2 Portable AP chest X-ray post-transfusion. Complete bilateral airspace opacities.

unifying themes among them are acute respiratory distress, new onset hypoxemia and bilateral pulmonary infiltrates on CXR that occur within 6 hours of a blood transfusion. ${ }^{12}$ TACO is the most frequent pulmonary-related transfusion complication and has recently surpassed TRALI as the leading cause of transfusion-related fatalities in the USA. ${ }^{3}$ The clinical presentation of TACO is related to pulmonary hydrostatic oedema and includes dyspnea, tachypnea, jugular venous distension and elevated systolic blood pressure. ${ }^{2}$ Conversely, the clinical presentation of TRALI is related to pulmonary permeability oedema, thought to occur secondary to the release of various leucocyte interleukins, and may include fever, hypotension, tachycardia and rarely a transient drop in the peripheral neutrophil count, though these features are often not present. ${ }^{2} \mathrm{~B}$-type natriuretic peptide (BNP) may be a distinguishing biomarker, as increased myocardial stretching in TACO can be assessed with an increase in pre-transfusion to post-transfusion BNP. ${ }^{2}$ Frustratingly, treatment is supportive for both syndromes. When any transfusion lung injury is suspected, the transfusion should be immediately stopped. When TACO is suspected, treatment includes supplemental oxygen, diuresis and assisted ventilation when indicated. Supportive treatment for TRALI includes supplemental oxygen, judicious fluid administration and in severe instances ventilatory and pharmacologic pressure support. Strategies to prevent TACO include screening transfusion recipients for occult cardiac insufficiency and reducing the volume and rate of transfusions. ${ }^{1}$ Strategies to prevent TRALI include increased donor HLA antibody screening, 
using male only plasma donors, and donor deferral based on history of transfusion. ${ }^{1}$ These TRALI mitigation strategies have drastically reduced the incidence of TRALI with 35 cases in 2006 compared with 9 cases in 2017, as reported by the Food and Drug Administration. ${ }^{3}$ Clinicians should be aware of TRALI and TACO and strategies to avoid these complications prior to ordering blood transfusions.

\section{Learning points}

- Transfusion-associated circulatory overload (TACO) and transfusion-related acute lung injury (TRALI) are acute respiratory distress syndromes which occur within 6 hours of a blood transfusion and associated with high mortality.

- Treatment of TACO and TRALI is largely supportive but intubation with pharmacologic pressure support may be required.

- The incidence of TRALI can be reduced with increased donor screening. The incidence of TACO can be reduced with increased recipient screening.
Contributors CMK contributed to the manuscript. CEM treated the patient and contributed to the manuscript. KFB provided edits.

Funding The authors have not declared a specific grant for this research from any funding agency in the public, commercial or not-for-profit sectors.

Competing interests None declared.

Patient consent for publication Not required.

Provenance and peer review Not commissioned; externally peer reviewed.

Open access This is an open access article distributed in accordance with the Creative Commons Attribution Non Commercial (CC BY-NC 4.0) license, which permits others to distribute, remix, adapt, build upon this work non-commercially, and license their derivative works on different terms, provided the original work is properly cited and the use is non-commercial. See: http://creativecommons.org/ licenses/by-nc/4.0/.

\section{REFERENCES}

1 Semple JW, Rebetz J, Kapur R. Transfusion-associated circulatory overload and transfusion-related acute lung injury. Blood 2019;133:1840-53.

2 Gajic O, Gropper MA, Hubmayr RD. Pulmonary edema after transfusion: how to differentiate transfusion-associated circulatory overload from transfusion-related acute lung injury. Crit Care Med 2006;34(5 Suppl):S109-13.

3 Fatalities Reported to Food and Drug Administration (FDA) Following Blood Collection and Transfusion; Annual Summary for Fiscal Year 2017. 2019 www.fda.gov/media/ 124796/downloads.

Copyright 2020 BMJ Publishing Group. All rights reserved. For permission to reuse any of this content visit https://www.bmj.com/company/products-services/rights-and-licensing/permissions/

BMJ Case Report Fellows may re-use this article for personal use and teaching without any further permission.

Become a Fellow of BMJ Case Reports today and you can:

- Submit as many cases as you like

- Enjoy fast sympathetic peer review and rapid publication of accepted articles

- Access all the published articles

- Re-use any of the published material for personal use and teaching without further permission

\section{Customer Service}

If you have any further queries about your subscription, please contact our customer services team on +44 (0) 2071111105 or via email at support@bmj.com.

Visit casereports.bmj.com for more articles like this and to become a Fellow 